\title{
Protein neutron diffraction experiment with dynamic nuclear polarization
}

\author{
I. Tanaka, H. Nishino, H. Yamauchi, Y. Noda, T. Maeda, S. Koizumi \\ Ibaraki University, Ibaraki, Japan \\ ichiro.tanaka.h27@vc.ibaraki.ac.jp
}

The dynamic nuclear polarization method in neutron diffraction can increase the detection sensitivity of hydrogen. It is expected that the scattering length of hydrogen becomes about 8 times larger at maximum and high $\mathrm{S} / \mathrm{N}$ ratio data can be obtained even with hydrogenated samples, not deuterated ones [1]. In order to realize the method, some radical molecules as an unpaired electron should be introduced into the sample, and high magnetic field (several T) and very low temperature (about $1 \mathrm{~K}$ ) should be applied. In the previous study, the polarization ratio of $22.3 \%$ was obtained with lysozyme protein polycrystal in TEMPOL (4 - Hydroxy - 2, 2, 6, 6 tetramethylpiperidine - 1 - oxyl) $50 \mathrm{mM}$ with a normal-conducting magnet of $2.5 \mathrm{~T}$ under off-beam condition [2]. This time, to achieve a higher polarization rate and to obtain a diffraction image using a polarized neutron beam, a nuclear polarization experiment of protein polycrystal was conducted using a super-conducting $7 \mathrm{~T}$ magnet installed at BL20 in MLF in J-PARC [3].

Both lysozyme and TEMPOL were purchased from Merck. Lysozyme polycrystal was made from several $1.5 \mathrm{~mL}$-solutions of 60 $\mathrm{mg} / \mathrm{mL}$ lysozyme, $100 \mathrm{mM}$ TEMPOL and $9 \%$ (wt/vol) $\mathrm{NaCl}$ in $50 \mathrm{mM}$ sodium acetate buffer of $\mathrm{pH} 4.5$ by batch method. About 100 mg polycrystal was mixed with $30 \%(\mathrm{wt} / \mathrm{vol})$ glycerol, then it was sealed within a cell made from Teflon and quartz windows. Incident neutron was polarized to $93 \%$ negatively. And sample was polarized at $1.2 \mathrm{~K}$ to $68 \%$ positively, to $59 \%$ negatively and to 0 $\%$ under equilibrium at $4.2 \mathrm{~K}$. The total exposure times were $4 \mathrm{hr}, 2.5 \mathrm{hr}$ and $1 \mathrm{hr}$, respectively. The proton power was $600 \mathrm{~kW}$, the applied magnetic field was $7 \mathrm{~T}$, and the microwave frequency was $188 \mathrm{GHz}$.

According to I (Q) graph integrated from 4 to $9 \AA$, several powder diffraction peaks were observed at around 0.1-0.2 $\AA^{-1}$ (Fig.1). Depending upon sample polarization rates, the different background levels and different peak intensities were observed clearly. If the lysozyme crystal space group is tetragonal form $\left(\mathrm{P}_{3} 2_{1} 2\right)$, the maximum peaks around at $\mathrm{q}=0.1 \AA^{-1}$ were (110) reflections whose dspacings were about $60 \AA$.



Figure 1. Diffraction patterns for each polarization rate of sample; $0 \%$ (black diamond), $+68 \%$ (blue cross) and $-59 \%$ (red plus).

[1] Niimura, N. \& Pojarny, A. (2011). Neutron Protein Crystallography. New York: Oxford University Press.

[2] Tanaka, I., Komatsuzaki, N., Yue, W.-X., Chatake, T., Kusaka, K., Niimura, N., Miura, D., Iwata, T., Miyachi, Y., Nukazuka, G. \& Matsuda, H. (2018). Acta Cryst. D 74, 787.

[3] Noda, Y. \& Koizumi, S. (2019). Nucl. Inst. and Meth. A 923, 127.

Keywords: dynamic nuclear polarization; protein crystal; neutron diffraction

Acta Cryst. (2021), A77, C1099 